\title{
Aplikasi Integrasi Pupuk NPK Dengan Waktu Pemberian Pupuk Organik Cair Pada Tanaman Pakcoy (Brassica rapa L.)
}

\section{Application of Integration of NPK Fertilizer with the Time of Liquid Organic Fertilizer on Brassica rapa $L$.}

\author{
Yance N. Ayal ${ }^{1}$, Henry Kesaulya ${ }^{2, *}$, Francina Matulessy ${ }^{2}$ \\ ${ }^{1)}$ Program Studi Agroekoteknologi Jurusan Budidaya Pertanian, Fakultas Pertanian Universitas Pattimura, Jl. Ir. M. \\ Putuhena Kampus Poka Ambon 97233, Indonesia \\ ${ }^{2)}$ Jurusan Budidaya Pertanian Fakultas Pertanian Universitas Pattimura, Jl. Ir. M. Putuhena Kampus Poka Ambon \\ 97233, Indonesia \\ *Penulis Korespondensi: henry.unpat@gmail.com
}

\begin{abstract}
This research was aimed to get the optimum NPK fertilizer dosage with the time of liquid organic fertilizer application to support the growth and yield of pakcoy (Brassica rappa L.). The study used a Randomized Block Design with three replications. Observation variables included plant height, leaf number, leaf area, total plant weight, root length, root weight and total plant weight percentage. The results showed that NO (without NPK fertilizer) was the best based on the plant height and leaf number. Liquid organic fertilizer given at 3-time applications per plant (W3) contributed significantly to leaf number at 35 days after planting and gave the highest yield of leaves, with 17,45 leaves. The treatment of NPK compound fertilizer dosage with the time of liquid organic fertilizer gave significant effects on the leaf area, total plant weight, root length, and root weight.
\end{abstract}

Keywords: liquid organic fertilizer, NPK, pakcoy

\begin{abstract}
ABSTRAK
Penelitian ini bertujuan untuk mendapatkan dosis pupuk NPK dengan waktu plikasi pupuk organik cair yang tepat untuk menunjang pertumbuhan danp roduksi tanaman pakcoy (Brassica rappa L.). Penelitian mengunakan Rancangan Acak Kelompok dengan tiga ulangan. Peubah-peubah pengamatan meliputi tinggi tanaman, jumlah daun, luas daun, berat total tanaman, panjang akar, berat akar dan persentase berat total tanaman. Hasil penelitian menunjukkan bahwa perlakuan N0 (tanpa pupuk NPK) merupakan yang terbaik dari penelitian ini terhadap parameter tinggi tanaman dan jumlah daun. Waktu pemberian pupuk organik cair 3 kali/tanaman (perlakuan W3) memberikan kontribusi yang signifikan terhadap jumlah daun 35 hari setelah tanam dan menghasilkan daun terbanyak dengan jumlah 17,45 helai. Perlakuan dosis pupuk majemuk NPK dengan waktu pemberian pupuk organik cair memberikan pengaruh yang nyata sampai sangat nyata terhadap luas daun, berat total tanaman, panjang akar serta berat akar.
\end{abstract}

Kata kunci: NPK, pakcoy, pupuk organik cair

\section{PENDAHULUAN}

Produktivitas tanaman sayuran, terutama pakcoy masih tergolong sangat rendah karena disebabkan oleh beberapa faktor antara lain: teknik budidaya yang belum intensif, faktor iklim dan tingkat kesuburan tanah yang rendah. Usaha untuk meningkatkan produktivitas tanaman tersebut salah satunya dengan pemberian pupuk. Tanaman sayuran terutama sayuran daun berumur pendek membutuhkan pemupukan. Oleh karena itu pemupukan merupakan hal penting dalam budidaya tanaman sayuran. Pupuk majemuk NPK dan pupuk organik cair merupakan pupuk yang banyak beredar di pasaran dan telah banyak digunakan oleh petani. Pupuk organik cair dapat memperbaiki sifat fisik, kimia dan biologis tanah, serta meningkatkan produksi tanaman, meningkatkan kualitas produk tanaman, mengurangi pengunaan pupuk anorganik dan sebagai alternatif pengganti pupuk kandang (Parman, 2007). Penggunaan pupuk organik cair juga dapat meningkatkan pembentukan klorofil daun, meningkatkan vigor tanaman sehingga tanaman menjadi kokoh serta meningkatkan daya tahan tanaman terhadap kekeringan (Rizqiani et al., 2007).

Pupuk organik cair dapat dibuat dari bahanbahan organik disekitar lingkungan tempat tinggal, dapat berupa sampah organik rumah tangga, limbah pertanian dan kotoran ternak, hal ini sesuai dengan pernyataan Nassaruddin dan Rosmawati (2011) Sumber bahan baku 
pupuk organik tersedia dimana saja dengan jumlah yang melimpah yang semuanya dalam bentuk limbah, baik limbah rumah tangga, rumah makan, pasar pertanian, peternakan, maupun limbah organik jenis lain. Revitalisasi pemulihan dan peningkatan produktivitas lahan secara berkelanjutan dapat dilakukan dengan meningkatkan peranan pupuk organik cair yang diperkaya dengan mikroba plant promoting rhizobacteria (PGPR) sebagai biostimulan (Kesaulya 2015; Kesaulya et al., 2015a, 2015b, 2015c; Kesaulya et al., 2017). Mikroba yang terdapat pada pupuk organik cair dapat berpengaruh terhadap proses fisiologis dan metabolisme tanaman serta mendukung kesuburan tanah (Nardy et al., 2009). Kompleksitas senyawa bioaktif pada pupuk organik cair sangat berperan pada pertumbuhan dan produksi tanaman, oleh karena itu aktifitas pupuk organik cair harus didasarkan atas mekanisme kerja bahan aktif atau pada respons fisiologis tanaman, selain itu juga sangat dipengaruhi oleh komposisi bahan penyusun pupuk organik cair. Aplikasi pupuk organik cair pada tanaman mampu meningkatkan prkembangan tanaman (Berlyn dan Russo 1990; Petrozza et al., 2013a, 2013b), karena berpengaruh terhadap penyerapan unsur hara dalam tanah (Banks dan Percival, 2012).

Pupuk organik cair yang diintegrasikan dengan pupuk anorganik dalam hal ini pupuk majemuk (NPK) guna menopang pertumbuhan dan produksi tanaman. Hal ini dilakukan untuk menghindari kebiasaan petani yang selalu bergantung pada pupuk anorganik yang pasokannya kadang kala terbatas dan harganya yang relatif mahal. Selain itu penggunaan pupuk NPK dengan dosis yang tinggi dan terus menerus dapat menyebabkan kerusakan pada lingkungan, oleh sebab itu penggunaan dosis pupuk harus mempertimbangkan secara baik tingkat produktivitas tanah dan kebutuhan tanaman dengan perlindungan terhadap lingkungan sekitar (Susila, 2013). Penelitian ini bertujuan untuk mendapatkan dosis pupuk NPK dan waktu aplikasi pupuk organik cair yang tepat untuk menunjang pertumbuhan dan produksi tanaman pakcoy (Brassica rappa $\mathrm{L}$ ).

\section{METODE PENELITIAN}

Penelitian ini dilaksanakan di rumah kaca Fakultas Pertanian Universitas Pattimura Ambon Maret hingga Mei 2017. Formulasi pupuk organik cair dilakukan pada laboratorium fisiologi tanaman Fakultas Pertanian Universitas Pattimura yang berlangsung mulai Januari hingga Februari 2017. Penelitian ini dilaksanakan dalam bentuk percobaan dua faktor dalam rancangan acak kelompok dengan tiga ulangan. Faktor perlakuan pertama adalah pemberian pupuk majemuk NPK (N) dengan taraf dosis yaitu tanpa pemberian pupuk NPK $\left(\mathrm{N}_{0}\right)$, dosis Pupuk NPK $1 \mathrm{~g} / \operatorname{tanaman}\left(\mathrm{N}_{1}\right)$, Dosis Pupuk NPK $2 \mathrm{~g} /$ tanaman $\left(\mathrm{N}_{2}\right)$, dan dosis Pupuk NPK $3 \mathrm{~g} /$ tanaman $\left(\mathrm{N}_{3}\right)$, sedangkan faktor perlakuan kedua adalah waktu pemberian pupuk organik cair (W) yang terdiri atas tanpa pemberian pupuk organik cair $\left(\mathrm{W}_{0}\right)$, pemberian pupuk organik cair 1 kali $\left(\mathrm{W}_{1}\right)$, pemberian pupuk organik cair 2 kali $\left(\mathrm{W}_{2}\right)$, pemberian pupuk organik cair 3 kali $\left(\mathrm{W}_{3}\right)$, dan pemberian pupuk organik cair 4 kali $\left(\mathrm{W}_{4}\right)$.

Pengamatan yang dilakukan terhadap peubah pertumbuhan dan produksi yakni meliputi tinggi tanaman, jumlah daun, luas daun, berat basah total tanaman, Panjang akar, berat akar, dan persentasi berat total tanaman. Tinggi tanaman $(\mathrm{cm})$ diketahui dengan cara mengukur tinggi tanaman sampel dari pangkal batang sampai titik tumbuh batang utama. Pengamatan dilakukan setiap 1 minggu sekali, saat tanaman berumur 14 hari setelah tanam sampai tanaman berumur 35 hari setelah tanam. Jumlah daun (helai) dihitung semua daun yang telah membuka sempurna. Pengamatan dilakukan setiap 1 minggu sekali, saat tanaman berumur 14 hari setelah tanam sampai tanaman berumur 35 hari setelah tanam. Pengukuran luas daun $\left(\mathrm{cm}^{2}\right)$ dilakukan dengan mengambil tiga helaian daun dari tiap tanaman dan diukur dengan menggunakan alat LA meter. Berat Basah Total tanaman (g) diamati adalah berat basah total tanaman diukur dengan menimbang hasil panen tanaman dengan mengunakan timbangan. Panjang akar $(\mathrm{cm})$ dihitung pada saat tanaman pakcoy dipanen. Berat akar (g) dihitung pada saat tanaman pakcoy dipanen. Persentase berat total tanaman (g) terhadap kontrol NPK dan waktu pemberian dihitung dengan menggunakan rumus:

$$
\text { Persentasi Berat Total }(\%)=\frac{Y_{\text {perlakuan }}-Y_{\text {kontrol }}}{Y_{\text {Kontrol }}} \times 100 \%
$$

Data dianalisis dengan menggunakan analisis ragam. Apabila terdapat pengaruh nyata dan sangat nyata, maka dilanjutkan dengan uji beda nyata jujur (BNJ) taraf 0,05.

\section{HASIL DAN PEMBAHASAN}

\section{Tinggi Tanaman}

Hasil uji BNJ terhadap tinggi tanaman yang diperlihatkan pada Gambar 1 menunjukkan bahwa pada pengamatan 14, 21, 28 dan 35 HST, tanaman pakcoy yang tanpa diberikan perlakuan pupuk NPK memiliki nilai tertinggi dibandingkan perlakuan pemupukan NPK lainnya. Peubah tinggi tanaman pada 14 dan 21 HST memperlihatkan bahwa tanaman pakcoy yang tanpa diberikan perlakuan pupuk NPK atau tanaman kontrol $\left(\mathrm{N}_{0}\right)$ menghasilkan tinggi tanaman yang tertinggi, tetapi tidak berbeda nyata dengan perlakuan $\mathrm{N}_{1}$ (perlakuan NPK $1 \mathrm{~g}$ /tanaman) dan berbeda nyata dengan $\mathrm{N}_{2}$ (perlakuan NPK $2 \mathrm{~g} /$ tanaman) dan $\mathrm{N}_{3}$ (perlakuan NPK 3 $\mathrm{g} /$ tanaman). Untuk perlakuan yang mendapatkan nilai terendah ditunjukan pada perlakuan $\mathrm{N}_{3}$ (perlakuan NPK $3 \mathrm{~g} /$ tanaman) dan secara statistik tidak berbeda nyata dengan perlakuan $\mathrm{N}_{2}$ (perlakuan NPK $2 \mathrm{~g} /$ tanaman). Pengamatan tinggi tanaman pada 28 HST dan 35 HST memperlihatkan bahwa perlakuan tanpa pupuk NPK $\left(\mathrm{N}_{0}\right)$ menunjukkan nilai tertinggi dan tidak berbeda nyata dengan perlakuan $\mathrm{N}_{1}$ dan $\mathrm{N}_{2}$ tetapi berbeda nyata dengan perlakuan $\mathrm{N}_{3}$. 


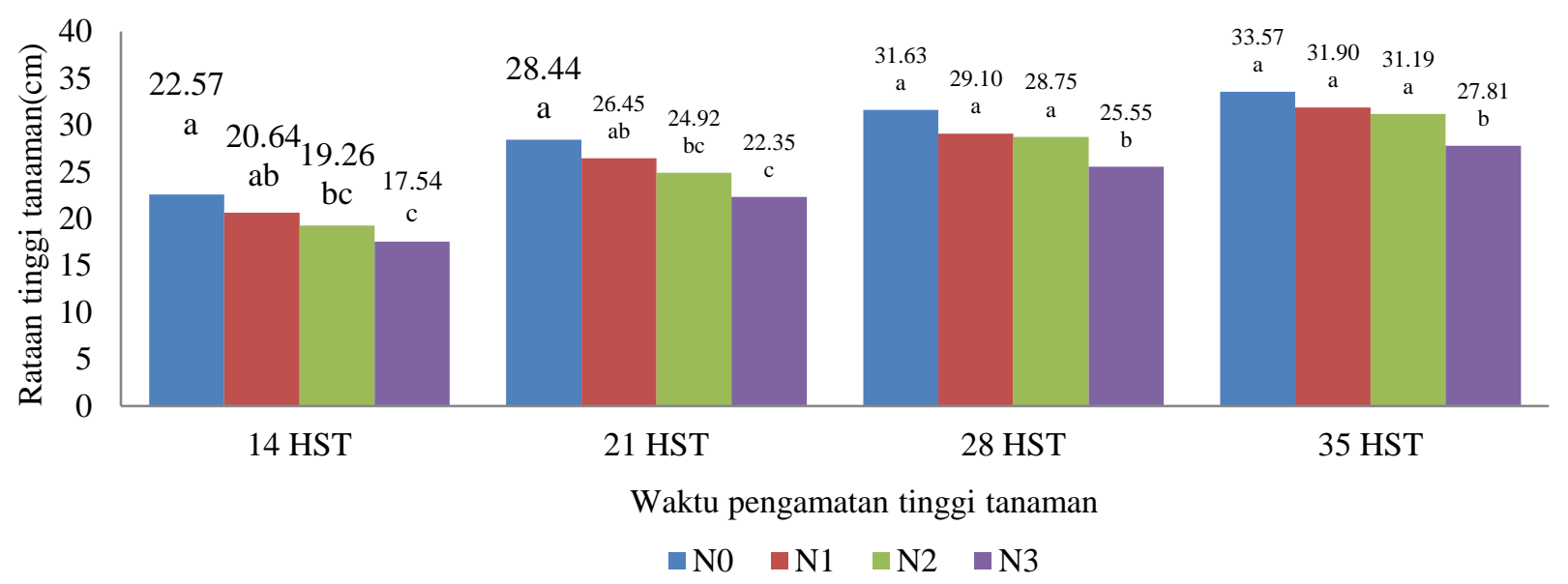

Keterangan: Angka yang diikuti huruf yang sama pada grafik tidak berbeda nyata pada taraf uji BNJ 0,05 (BNJ pada 14 HST = 2,70; 21 HST $=2,93 ; 28$ HST $=2,90$; dan 35 HST $=2,88$ )

Gambar 1. Rata-rata tinggi tanaman pakcoy (cm) umur 14-35 HST

\section{Jumlah Daun}

Hasil uji BNJ terhadap jumlah daun tanaman pakcoy yang diperlihatkan pada Gambar 2 menunjukan bahwa pada pengamatan 14, 21, 28 dan 35 HST, tanaman pakcoy yang tanpa diberikan perlakuan pupuk NPK memiliki jumlah daun terbanyak dibandingkan dengan perlakuan pemupukan NPK lainnya. Peubah jumlah daun tanaman pada 14, 21 dan 28 HST memperlihatkan bahwa tanaman pakcoy tanpa diberikan perlakuan pupuk NPK atau tanaman kontrol $\left(\mathrm{N}_{0}\right)$ menghasilkan jumlah daun tanaman yang terbanyak, tetapi tidak berbeda nyata dengan perlakuan $\mathrm{N}_{1}$ (perlakuan NPK $1 \mathrm{~g} /$ tanaman), $\mathrm{N}_{2}$ (perlakuan NPK 2 g/tanaman) tetapi berbeda nyata dengan perlakuan $\mathrm{N}_{3}$ (perlakuan NPK $3 \mathrm{~g} /$ tanaman).
Pengamatan jumlah daun tanaman pada 35 HST memperlihatkan bahwa perlakuan pupuk NPK 1 $\mathrm{g} /$ tanaman $\left(\mathrm{N}_{1}\right)$ menghasilkan jumlah daun terbanyak dan tidak berbeda nyata dengan perlakuan $\mathrm{N}_{0}$ (tanaman kotrol) berbeda nyata dengan perlakuan $\mathrm{N}_{2}$ (perlakuan NPK $2 \mathrm{~g} /$ tanaman) dan perlakuan $\mathrm{N}_{3}$ (perlakuan NPK 3 $\mathrm{g} /$ tanaman. Disamping itu perlakuan waktu pemberian pupuk organik cair memberikan pengaruh yang nyata selain pemberian pupuk NPK. Dilain pihak pada Gambar 8 memperlihatkan waktu pemberian pupuk organik cair pada waktu aplikasi $\mathrm{W}_{3}$ (aplikasi 3 kali) berpengaruh pada pertambahan jumlah daun sebesar (17,45 daun) dan berbeda nyata dengan perlakuan $\mathrm{W}_{2}$ (waktu aplikasi POC 2 kali), $\mathrm{W}_{4}$ (waktu aplikasi 4 kali), $\mathrm{W}_{1}$ (waktu aplikasi 1 kali), dan $\mathrm{W}_{0}$ (tanpa pemberian POC).

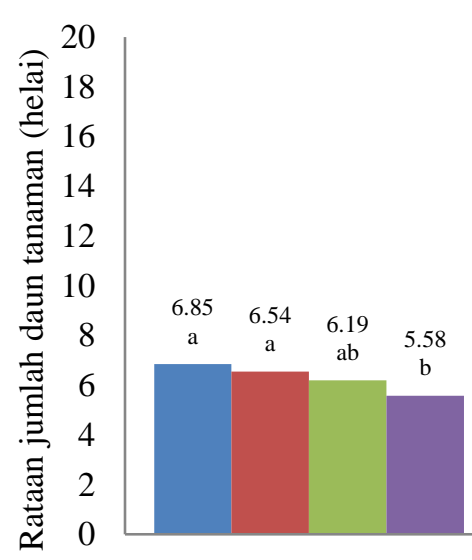

14 HST

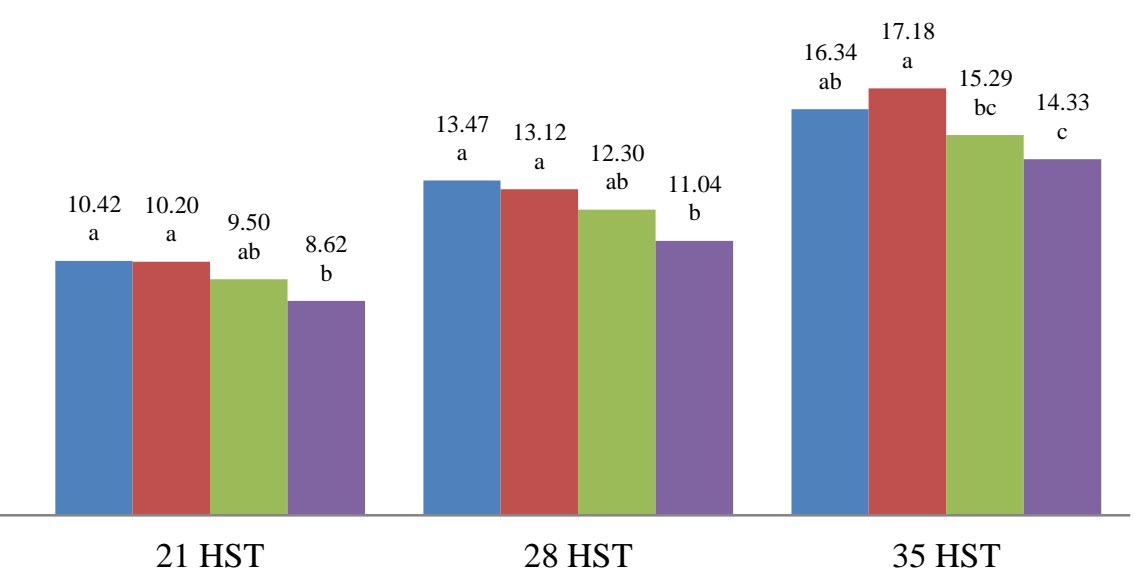

Waktu pengamatan jumlah daun tanaman

$$
\square \mathrm{N} 0 \quad \square \mathrm{N} 1 \quad \square \mathrm{N} 2 \quad \square \mathrm{N} 3
$$

Keterangan: Angka yang diikuti huruf yang sama pa grafik tidak berbeda nyata pada taraf uji BNJ 0,05 (BNJ pada 14 HST = 0,84; $21 \mathrm{HST}=1,14 ; 28 \mathrm{HST}=1,56$; dan $35 \mathrm{HST}=1,79$ )

Gambar 2. Rata-rata jumlah daun tanaman pakcoy (helai) pada umur 14-35 HST 


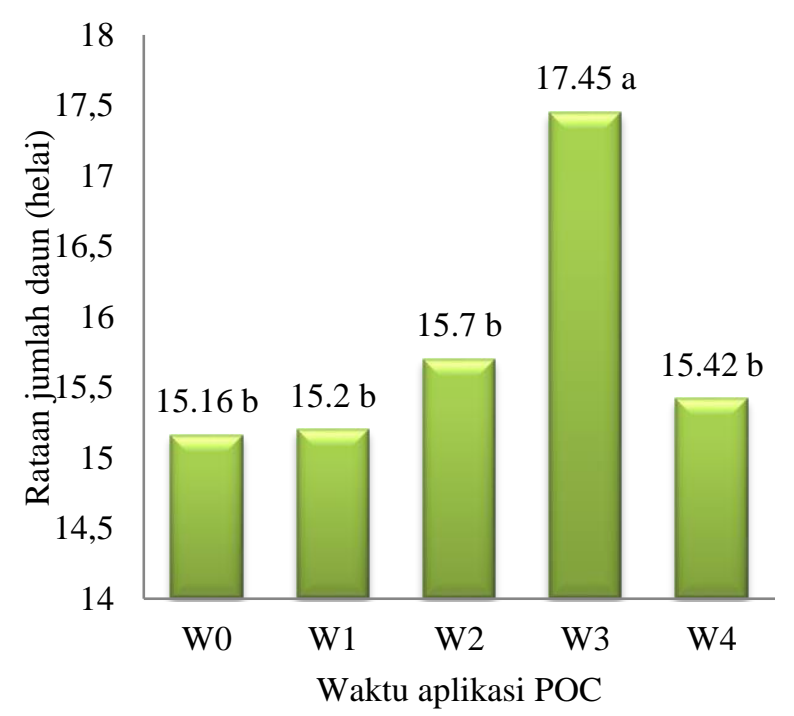

Keterangan: Angka yang diikut huruf yang sama pa grafik tidak berbeda nyata pada taraf uji BNJ 0,05 (BNJ pada $35 \mathrm{HST}=1,53$ )

Gambar 3.Pengaruh waktu pemberian poc terhadap jumlah daun tanaman Pakcoy (helai) pada 35 HST

\section{Luas Daun}

Hasil uji BNJ terhadap luas daun tanaman yang diperlihatkan pada Tabel 1 menunjukan bahwa perlakuan interaksi $\mathrm{N}_{0} \mathrm{~W}_{1}$ (perlakuan tanpa pupuk NPK dengan waktu aplikasi pupuk organik cair 1 kali) berpengaruh terhadap luas daun dan berbeda nyata dengan seluruh interaksi perlakuan lainnya dan memiliki luas daun terbesar.

\section{Panjang dan Berat Akar}

Terhadap peubah panjang akar tanaman, perlakuan $\mathrm{N}_{0} \mathrm{~W}_{2}$ (perlakuan dengan tanpa NPK dengan waktu aplikasi pupuk organik cair 2 kali) memberikan kontribusi terhadap panjang akar sebesar $(13,98 \mathrm{~cm})$ dan merupakan akar terpanjang dibandingkan dengan interaksi perlakuan lainnya (Tabel 3).

Berat akar tanaman dari hasil yang disajikan terlihat pada Tabel 1 memperlihatkan bahwa akar tanaman terberat $(8,66 \mathrm{~g})$ didapati pada perlakuan $\mathrm{N}_{1} \mathrm{~W}_{0}$ (perlakuan NPK $1 \mathrm{~g} /$ tanaman dengan tanpa aplikasi pupuk organik cair) dan secara statistik berbeda nyata dengan seluruh interaksi perlakuan yang dicobakan.

\section{Produksi Biomasa Tanaman Pakcoy}

Pengamatan berat total tanaman seperti yang disajikan pada Tabel 2 memperlihatkan bahwa berat total tanaman dipengaruhi oleh pemberian perlakuan pemupukan NPK dan waktu aplikasi pupuk organik cair, dimana perlakuan $\mathrm{N}_{0} \mathrm{~W}_{4}$ (perlakuan tanpa NPK dengan waktu aplikasi pupuk organik cair 4 kali) dapat memacu berat total tanaman tertinggi (218 g) dan secara statistik berbeda dengan 19 interaksi perlakuan lainnya dan yang mendapatkan berat tanaman terkecil diperlihatkan oleh perlakuan $\mathrm{N}_{3} \mathrm{~W}_{4}$ (perlakuan NPK $3 \mathrm{~g}$ /tanaman dengan waktu aplikasi pupuk organik cair 4 kali).

Tabel 1. Rata-rata luas daun, panjang akar dan berat akar tanaman Pakcoy (helai) pada umur 14-35HST

\begin{tabular}{|c|c|c|c|c|}
\hline \multicolumn{2}{|c|}{ Perlakuan } & \multicolumn{3}{|c|}{ Rata-rata Luas Daun, Panjang dan Berat Akar } \\
\hline $\begin{array}{c}\text { NPK } \\
\text { (g/tanaman) }\end{array}$ & $\begin{array}{c}\text { Pupuk organik } \\
\text { cair (pemberian) }\end{array}$ & Luas daun $\left(\mathrm{cm}^{2}\right)$ & Panjang akar $(\mathrm{cm})$ & Berat akar $(g)$ \\
\hline \multirow[t]{5}{*}{0} & 0 & $98,25 \mathrm{~d}$ & $7,86 \mathrm{ij}$ & $2,33 \mathrm{f}$ \\
\hline & 1 & $114,64 \mathrm{a}$ & $9,2 \mathrm{fg}$ & $2,33 \mathrm{f}$ \\
\hline & 2 & $110,30 \mathrm{~b}$ & $13,98 \mathrm{a}$ & $6 \mathrm{~b}$ \\
\hline & 3 & $106,21 \mathrm{c}$ & $11,2 \mathrm{~d}$ & $3,66 \mathrm{e}$ \\
\hline & 4 & $110,84 \mathrm{~b}$ & $11,9 \mathrm{bc}$ & $4 \mathrm{~d}$ \\
\hline \multirow[t]{5}{*}{1} & 0 & $94,70 \mathrm{de}$ & $10,45 \mathrm{e}$ & 8,66 a \\
\hline & 1 & $75,61 \mathrm{i}$ & $8,16 \mathrm{~h} \mathrm{i}$ & $2 \mathrm{~g}$ \\
\hline & 2 & $92,19 \mathrm{e}$ & $7,26 \mathrm{j} \mathrm{k}$ & $5 \mathrm{c}$ \\
\hline & 3 & $96,91 \mathrm{~d}$ & $10,5 \mathrm{e}$ & $5 \mathrm{c}$ \\
\hline & 4 & $79,84 \mathrm{~h}$ & $9,63 \mathrm{f}$ & $2,33 \mathrm{f}$ \\
\hline \multirow[t]{5}{*}{2} & 0 & $66,45 \mathrm{j}$ & $8,6 \mathrm{~g} \mathrm{~h}$ & $1,33 \mathrm{i}$ \\
\hline & 1 & $41,80 \mathrm{~m}$ & $10,8 \mathrm{de}$ & $2 \mathrm{~g}$ \\
\hline & 2 & $88,79 \mathrm{f}$ & $12,25 \mathrm{~b}$ & $4 \mathrm{~d}$ \\
\hline & 3 & $79,90 \mathrm{~h}$ & $9,76 \mathrm{f}$ & $3,66 \mathrm{e}$ \\
\hline & 4 & $65,06 \mathrm{j} \mathrm{k}$ & $11,4 \mathrm{~cd}$ & $2 \mathrm{~g}$ \\
\hline \multirow[t]{5}{*}{3} & 0 & $63,01 \mathrm{k}$ & $7,96 \mathrm{i}$ & $1,66 \mathrm{~h}$ \\
\hline & 1 & $77,07 \mathrm{~h} \mathrm{i}$ & $9,76 \mathrm{f}$ & $2 \mathrm{~g}$ \\
\hline & 2 & 50,191 & $7,73 \mathrm{i} \mathrm{j}$ & $1,33 \mathrm{i}$ \\
\hline & 3 & $84,05 \mathrm{~g}$ & $6,96 \mathrm{k}$ & $1,33 \mathrm{i}$ \\
\hline & 4 & 47,321 & 5,951 & $1 \mathrm{j}$ \\
\hline BNJ 0,05 & & 2,97 & 0,59 & 0,19 \\
\hline
\end{tabular}

Keterangan: Angka-angka yang diikuti oleh huruf yang sama tidak berbeda nyata pada taraf uji BNJ 0,05. 
Pengamatan berat total tanaman seperti yang disajikan pada Tabel 2 memperlihatkan bahwa berat total tanaman dipengaruhi oleh pemberian perlakuan pemupukan NPK dan waktu aplikasi pupuk organik cair, dimana perlakuan $\mathrm{N}_{0} \mathrm{~W}_{4}$ (perlakuan tanpa NPK dengan waktu aplikasi pupuk organik cair 4 kali) dapat memacu berat total tanaman tertinggi (218 g) dan secara statistik berbeda dengan 19 interaksi perlakuan lainnya dan yang mendapatkan berat tanaman terkecil diperlihatkan oleh perlakuan $\mathrm{N}_{3} \mathrm{~W}_{4}$ (perlakuan NPK $3 \mathrm{~g}$ /tanaman dengan waktu aplikasi pupuk organik cair 4 kali) dan berbeda nyata dengan seluruh interaksi perlakuan lainnya.

Nilai persentase berat total tanaman seperti yang terlihat pada Tabel 2 lebih besar dari 100\% terhadap pembanding tanaman kontrol $\left(\mathrm{N}_{0} \mathrm{~W}_{0}\right)$ terdapat pada perlakuan $\mathrm{N}_{0} \mathrm{~W}_{4}$ dengan nilai $123,96 \%$ perlakuan $\mathrm{N}_{1} \mathrm{~W}_{0}$ dengan presentase $116,78 \%$ dan juga perlakuan $\mathrm{N}_{1} \mathrm{~W}_{3}$ yang mendapatkan nilai persentase sebesar $100,34 \%$. Selanjutnya yang memiliki persentase di atas $100 \%$ terhadap pembanding kontrol NPK atau perlakuan NPK $2 \mathrm{~g} /$ tanaman dengan tanpa aplikasi pupuk organik cair $\left(\mathrm{N}_{2} \mathrm{~W}_{0}\right)$ ditunjukan oleh perlakuan $\mathrm{N}_{2} \mathrm{~W}_{1}$ dengan nilai $160,22 \%$, perlakuan $\mathrm{N}_{2} \mathrm{~W}_{2}$ dengan persentase $187,71 \%$, perlakuan $\mathrm{N}_{2} \mathrm{~W}_{4}$ yang memiliki nilai presentase $218,42 \%$ kemudian perlakuan $\mathrm{N}_{3} \mathrm{~W}_{1}$ yang memiliki nilai persentase $123,96 \%$ serta perlakuan $\mathrm{N}_{3} \mathrm{~W}_{3}$ dengan nilai persentasenya sebesar $123,68 \%$. Produktivitas tanaman pakcoy diamati saat panen dengan menghitung berat total tanaman. Bila dilakukan pendekatan menggunakan kriteria RAE (relative agronomic effectiveness) yang dilakukan pada peubah berat total tanaman untuk mengetaui efektifitas perlakukan terhadap produktivitas saat panen (Anwar et al., 2001), maka semua perlakuan dengan nilai lebih besar dari $100 \%$ dapat dikatakan efektif terhadap produksi dan bila kurang dari $100 \%$ dikatakan tidak efektif.

\section{PEMBAHASAN}

Peubah tinggi dan jumlah daun pada penelitian ini memperlihatkan bahwa semakin tinggi dosis yang diaplikasikan maka hasilnya akan menurun atau tanaman tidak produktif. Hal ini sejalan dengan pendapat Putri (2016) yang menyatakan bahwa penggunaan pupuk anorganik secara berlebihan akan berdampak pada penurunan kualitas tanaman, kualitas tanah serta lingkungan. Winarso (2005) juga menambahkan bahwa pupuk yang diberikan secara berlebihan tidak dapat dimanfaatkan oleh tanaman, yang akhirnya justru berakibat tidak baik pada lingkungan yang ditunjukkan oleh rendahnya kualitas tanah. Hardjowigeno (2003) menjelaskan bahwa dosis pupuk yang diberikan untuk tanaman harus sesuai dengan kebutuhan tanaman akan unsur hara dan juga harus mempertimbangkan kadar unsur hara yang tersedia dalam tanah, sehingga pemberian pupuk tidak berlebihan dan percuma bagi tanaman. Selain itu pemupukan dengan dosis yang tinggi juga menyebabkan tanaman mengalami keracunan unsur hara.

Tabel 2. Rata-rata berat total tanaman, dan persentase berat total tanaman perlakuan terhadap kontrol pemupukan npk dan waktu pemberian POC

\begin{tabular}{|c|c|c|c|c|c|c|}
\hline \multicolumn{2}{|c|}{ Perlakuan } & \multirow{2}{*}{$\begin{array}{l}\text { Berat total } \\
\quad(\mathrm{g})\end{array}$} & \multirow[b]{2}{*}{ Persentase } & \multirow[b]{2}{*}{ Berat Total Tanaman } & \multirow{2}{*}{\multicolumn{2}{|c|}{ Perlakuan Terhadap Kontrol (\%) }} \\
\hline $\begin{array}{c}\text { NPK } \\
\text { (g/tanaman) }\end{array}$ & $\begin{array}{c}\text { Pupuk organik } \\
\text { cair (pemberian) }\end{array}$ & & & & & \\
\hline \multirow[t]{5}{*}{0} & 0 & $97,33 \mathrm{j}$ & 0 & - & - & - \\
\hline & 1 & $127,66 \mathrm{~h}$ & 31,16 & - & - & - \\
\hline & 2 & $187,33 \mathrm{~d}$ & 92,46 & - & - & - \\
\hline & 3 & $165,66 \mathrm{e}$ & 70,20 & - & - & - \\
\hline & 4 & 218 a & 123,98 & - & - & - \\
\hline \multirow[t]{5}{*}{1} & $\mathbf{0}$ & $211 \mathrm{~b}$ & 116,78 & 0 & - & - \\
\hline & 1 & $134,33 \mathrm{~g}$ & 38,01 & $-36,33$ & - & - \\
\hline & 2 & $184,33 \mathrm{~d}$ & 89,38 & $-12,63$ & - & - \\
\hline & 3 & $195 \mathrm{c}$ & 100,34 & $-7,58$ & - & - \\
\hline & 4 & $154 \mathrm{f}$ & 58,22 & $-27,01$ & - & - \\
\hline \multirow[t]{5}{*}{2} & 0 & $57 \mathrm{~m}$ & $-41,43$ & $-72,98$ & 0 & - \\
\hline & 1 & $148,33 \mathrm{f}$ & 52,39 & $-29,70$ & 160,22 & - \\
\hline & 2 & $164 \mathrm{e}$ & 68,49 & $-22,27$ & 187,71 & - \\
\hline & 3 & $83,5 \mathrm{k}$ & $-14,20$ & $-60,42$ & 46,49 & - \\
\hline & 4 & $181,5 \mathrm{~d}$ & 86,47 & $-13,98$ & 218,42 & - \\
\hline \multirow[t]{5}{*}{3} & 0 & 67,661 & $-30,48$ & $-67,93$ & 18,70 & 0 \\
\hline & 1 & $127,66 \mathrm{~h}$ & 31,16 & $-39,49$ & 123,96 & 88.67 \\
\hline & 2 & $103,66 \mathrm{i}$ & 6,50 & $-50,87$ & 81,85 & 53.20 \\
\hline & 3 & $127,5 \mathrm{~h}$ & 30,99 & $-39,57$ & 123,68 & 88.44 \\
\hline & 4 & $33 n$ & $-66,09$ & $-84,36$ & $-42,10$ & $-51,22$ \\
\hline
\end{tabular}

Keterangan: Angka-angka yang diikuti oleh huruf yang sama tidak berbeda nyata pada taraf uji BNJ 0,05. 
Faktor tunggal waktu pemberian pupuk organik cair (W) hanya berpengaruh nyata pada 35 HST yang ditemui pada peubah jumlah daun. Dan memperlihatkan bahwa tanaman pakcoy 35 hari setelah tanam memiliki daun terbanyak $(17,45)$ terdapat pada perlakuan waktu pemberian pupuk organik cair tiga kali $\left(\mathrm{W}_{3}\right)$ dan berbeda dengan semua perlakuan lainnya. Adanya respon pertumbuhan yang baik pada pemberian pupuk organik cair diakibatkan oleh adanya nutrisi berupa hara yang terkandung di dalamnya. Waktu pemberian pupuk organik cair yang sedikit pada penelitian ini memberikan hasil yang kecil, ini disebabkan kandungan hara dari pupuk organik cair yang sedikit belum bisa dimanfatkan tanaman karena pupuk organik cair memerlukan proses sehingga dapat tersedia bagi tanaman. Hardjowigeno (2003) mengemukakan bahwa salah satu kelemahan pupuk organik adalah kandungan hara yang rendah serta pengaruh terhadap tanaman sangat lamban. Meningkatnya jumlah daun pada hari 35 setelah tanam diakibatkan oleh kandungan hara $\mathrm{N}$ pada pupuk organik cair masih relatif kecil sehingga perlu waktu pemberian yang lebih banyak untuk menunjang ketersediaan unsur $\mathrm{N}$ bagi tanaman pakcoy.

Hasil analisis ragam menunjukkan bahwa interaksi antara pemberian dosis NPK $(\mathrm{N})$ dengan waktu pemberian pupuk organik cair (W) memberikan pengaruh yang nyata hingga sangat nyata terhadap peubah luas daun, berat total tanaman, panjang akar dan berat akar. Untuk peubah luas daun memperlihatkan bahwa daun terluas $\left(114,64 \mathrm{~cm}^{2}\right)$ terdapat pada interaksi antara konsentrasi tanpa NPK dengan waktu pemberian pupuk organik cair satu kali $\left(\mathrm{N}_{0} \mathrm{~W}_{1}\right)$ dan secara statistik berbeda nyata dengan semua intraksi perlakuan lainnya. Hal ini menunjukakan bahwa luas daun tanaman pakcoy dapat dicukupi oleh pemberian pupuk organik cair dengan waktu aplikasi satu kali/tanaman.

Daun sebagai organ penting tanaman, megandung klorofil dan sebagai tempat berlangsungnya proses fotosintesis, respirasi, serta transpirasi yang mempengaruhi arah pertumbuhan dan perkembangan tanaman (Santoso dan Haryadi, 2008). Menurut Fitter dan Hay (1998) luas daun menjadi penentu utama kecepatan pertumbuhan, semakin luas maka semakin besar juga menampung bahan-bahan untuk proses fotosintesis. Erawan et al. (2013) menyatakan bahwa meningkatnya luas daun tanaman dapat disebabkan oleh tersedianya nutrisi yang dapat diserap oleh tanaman, sehingga pertumbuhan tanaman seperti luas daun meningkat. Lakitan (2011) menambahkan bahwa tanaman yang mendapatkan nutrisi sesuai, mengalami partumbuhan yang baik, ditunjukkan dengan pertambahan tinggi dan daun yang terbentuk akan lebar. Dari hasil ini dapat diduga bahwa didalam pupuk organik cair yang digunakan pada penelitian ini, terdapat kandungan nutrisi yang cukup untuk menunjang pertumbuhan tanaman seperti luas daun tanaman pakcoy.

Interaksi perlakuan tanpa NPK dengan waktu pemberian pupuk organik cair dua kali $\left(\mathrm{N}_{0} \mathrm{~W}_{2}\right)$ memberikan hasil terbaik dengan panjang akar yaitu
$13,98 \mathrm{~cm}$, lebih panjang dibandingkan dengan perlakuan lainnya serta berbeda nyata dengan seluruh interaksi perlakuan lainnya. Hal ini mengindikasikan bahwa panjang akar tanaman mampu ditopang dengan pemberian pupuk organik sebanyak 2 kali hal ini tak sejalan dengan peubah berat akar yang mana pada peubah berat akar tanaman yang mempunyai akar terberat $(8,66 \mathrm{~g})$ di miliki oleh interaksi perlakuan NPK $1 \mathrm{~g} /$ tanaman dengan tanpa pemberian pupuk organik cair $\left(\mathrm{N}_{1} \mathrm{~W}_{0}\right)$ dan berbeda dengan semua perlakuan interaksi lainnya. Ini menunjukan bahwa berat organ akar tanaman pakcoy sangat dipacu oleh dosis pupuk NPK DGW $1 \mathrm{~g} /$ tanaman karena pada pupuk NPK DGW terdapat kandungan hara $\mathrm{P}$ sebesar $15 \%$ dan seperti di ketahui bahwa unsur hara $\mathrm{P}$ sangat membantu dalam proses pertumbuhan akar tanaman, hal ini sejalan dengan pendapat Marisi et al. (2014) unsur hara P juga memiliki tugas mengedarkan energi keseluruh bagian tanaman dan merangsang perkembangan akar.

Pengamatan terhadap berat total tanaman untuk interaksi perlakuan tanpa NPK dengan waktu pemberian pupuk organik cair 4 kali $\left(\mathrm{N}_{0} \mathrm{~W}_{4}\right)$ menghasilkan berat $218 \mathrm{~g}$ dan berbeda nyata dengan 19 interaksi perlakuan lainnya. Untuk berat total tanaman unsur hara yang diperlukan dalam jumlah banyak dan harus tersedia sepanjang waktu dan inilah yang menjadi faktor penentu mengapa tanaman pakcoy yang diberikan pupuk organik cair selama 4 kali memberi hasil yang sangat berat. Hal ini menunjukkan bahwa ketersediaan hara melalui pemberian pupuk organik cair mampu menunjang pertumbuhan vegetatif tanaman secara optimal. Ketersediaan unsur hara merupakan salah satu faktor lingkungan yang sangat menentukan laju pertumbuhan tanaman (Gardner et al., 1985). Sehingga dibutuhkan lebih banyak unsur hara esensial yang tersedia dan dapat diperoleh melalui peningkatan waktu aplikasi pupuk organik cair. Peningkatan berat total tanaman dapat mencapai hasil yang optimal, karena tanaman memperoleh hara yang sesuai untuk pertumbuhan dan perkembangan dari pupuk organik cair sehingga peningkatan jumlah maupun ukuran sel mencapai optimal.

Persentase berat total tanaman terhadap kontrol memperlihatkan bahwa perlakuan yang efektif memiliki nilai persentase diatas seratus persen. Beberapa perlakuan yang efektif terdiri dari perlakuan tanpa NPK dengan waktu aplikasi pupuk organik cair empat kali $\left(\mathrm{N}_{0} \mathrm{~W}_{4}\right)$ memiliki nilai efektivitas $123,98 \%$, dosis NPK $1 \mathrm{~g} /$ tanaman dengan tanpa waktu pemberian pupuk organik cair $\left(\mathrm{N}_{1} \mathrm{~W}_{0}\right)$ nilai efektivitas $116,78 \%$ dan perlakuan dosis NPK $1 \mathrm{~g} /$ tanaman dengan waktu pemberian pupuk organik cair tiga kali $\left(\mathrm{N}_{1} \mathrm{~W}_{3}\right)$ mendapatkan nilai efektivitas sebesar 100,34\%. Hal ini menunjukkan bahwa pada penelitian hanya terdapat tiga perlakuan yang efektif dan perlakuan lainnya tidak efektif. Efektifnya tiga perlakuan ini didukung oleh kecukupan hara tanaman yang mampu disediakan oleh pupuk organik cair dan pupuk NPK. Dengan pemberian dosis dan waktu pemberian yang sesuai dapat menunjang berat total tanaman pakcoy. 


\section{KESIMPULAN}

Berdasarkan hasil penlitian yang diperoleh maka dapat disimpulkan bahwa :

1. Pupuk majemuk NPK dengan dosis pupuk majemuk NPK 1 g/tanaman $\left(\mathrm{N}_{1}\right)$ merupakan dosis terbaik dari penelitian ini, meskipun bukan yang tertinggi terhadap variable tinggi tanaman dan jumlah daun namun, dosis $1 \mathrm{~g} /$ tanaman sama atau tidak berbeda nyata dengan $\left(\mathrm{N}_{0}\right)$.

2. Waktu pemberian pupuk organik cair $3 \mathrm{kali} / \mathrm{tanaman}$ (perlakuan $\mathrm{W}_{3}$ ) memberikan kontribusi yang signifikan terhadap jumlah daun 35 HST dan merupakan daun terbanyak dengan jumlah 17,45 helai.

3. Perlakuan dosis pupuk majemuk NPK dengan waktu pemberian pupuk organik cair memberikan pengaruh yang nyata sampai sangat nyata pada variable luas daun, berat total tanaman, panjang akar serta berat akar.

\section{DAFTAR PUSTAKA}

Anwar, Ea.K., dan S. Gitosuswondo. 2001. Effectiveness of commercial biofertilizer on fertilization efficiency in ultisol for the growth and yield of caisin. Journal Trop. Soils 16: 191-199.

Erawan, D., W.O. Yani, dan A. Bahrun. 2013. Pertumbuhan dan hasil tanaman sawi (Brassica juncea L.) pada berbagai dosis pupuk urea. Jurnal Agroteknos 3: 19-25.

Fitter, H. dan M. Hay. 1998. Fisiologi Lingkungan Tanaman. Gadjah Mada University Press. Yogyakarta.

Gardner, F.P., B.R. Pearce, and R.L. Mitchell. 1985. Physiology of Crop Plants. The Iowa State University Press, Iowa.

Hardjowigeno, S. 2003. Ilmu Tanah. Penerbit Akademika Pressindo, Jakarta.

Kesaulya, H., J.V. Hasinu, and G.N.C. Tuhumury. 2017 Potency of Bacillus spp from potato rhizosphere as active ingredients for biostimulan formulation. Modern Applied Science 11: 74-80.

Kesaulya, H. 2015. Bioprospek Rizobakteria Asal Kentang (Solanum tuberosum L.) Var. Hartapel sebagai pemacu pertumbuhan tanaman. Disertasi. Universitas Hasanuddin.

Kesaulya, H., Baharuddin, B. Zakaria, and S.A. Syaiful. 2015a. Isolation and Physiological Characterization of PGPR from Potato Plant Rhizosphere in Medium Land of Buru Island. Procedia Food Science 3: 190-199.

Kesaulya, H., Baharuddin, B. Zakaria, and S.A. Syaiful. 2015b. The ability phosphate solubilization of bacteria of bacteria rhizosphere of potato var. Hartapel from Buru Island. International Journal of Current Microbiology Applied Science 4: 404409.

Kesaulya, H., Baharuddin, B. Zakaria, and S.A. Syaiful. 2015c. Potential rhizosphere bcteria originated from potato var. Hartapel from Buru Island as plant growth promoters. International Journal of Scientific \& Technology Research 4: 361-363.

Lakitan, B. 2011. Dasar-dasar Fisiologi Tumbuhan. Jakarta: Rajawali Pers

Marisi, N., A.P. Sujalu, dan M. Hendri. 2014. Pengaruh Pupuk NPK Mutiara Dan Pupuk Kandang Sapi Terhadap Pertumbuhan Dan Hasil Tanaman Terung (Solanum melogena L). Universitas 17 Agustus 1945. Samarinda.

Nardi, S., P. Carletti, D. Pizzeghello, and A. Muscolo. 2009. Biological Activities of Humic Substances. In: Senesi, N., B. Xing, P.M. Huang (Eds). Biophysico-Cemical Processes Involving Natural Nonliving Organic Matter in Environmental System. Vol 2. Hoboken, NJ: Wiley; p. 305-340.

Nassaruddin, dan Rosmawati. 2011. Pengaruh pupuk organik cair (POC) hasil fermentasi daun gamal, batang pisang dan sabut kelapa terhadap pertumbuhan bibit kakao. Agrisistem 7: 29-37.

Parman, S. 2007. Pengaruh pemberian pupuk organik cair terhadap pertumbuhan dan produksi kentang (Solanum tuberosum L.). Buletin Anatomi dan Fisiologi 15: 21-31.

Petrozza, A., S. Summerer, G.D. Tommaso, D.D. Tommaso, and A. Piaggesy. 2013a. Evaluation of the effects of Radifarm ${ }^{\circledR}$ treatment on the morphophysiological characteristics of root systems via image analysis. Acta Horticulturae 1009: 149-153.

Petrozza, A., S. Summerer, G.D. Tommaso, D.D. Tommaso, and A. Piaggesy. 2013b. An evaluation of tomato plant root development and morpho-physiological response treated with VIVA by image analysis. Acta Horticulturae 1009: 155-159.

Putri, S.L. 2016. Pengaruh Pemberian Dosis Pupuk NPK dan Pupuk Hayati Terhadap Pertumbuhan dan Produksi Tanaman Sedap Malam (Polianthes tuberosa L). Skripsi. Universitas Lampung.

Rizqiani, N.F., E. Ambarwati, dan N.W. Yuwono. 2007. Pengaruh dosis dan frekuensi pemberian pupuk organik cair terhadap pertumbuhan dan hasil buncis (Phaseolus vulgaris L.) dataran rendah. Jurnal Ilmu Tanah dan Lingkungan 7: 43-53.

Santoso, B. dan Hariyadi. 2008. Metode pengukuran luas daun jarak pagar. Magrobis Jurnal IlmuIlmu Pertanian 8: 17-22.

Saribun, D.S. 2008. Pengaruh pupuk majemuk NPK pada berbagai dosis terhadapa $\mathrm{pH}, \mathrm{P}$-potensial, dan $P$ tersedia serta hasil caysin pada fluventic eutrudepts Jatinangor. Universitas Padjadjaran.

Susila, A.D. 2013. Pemupukan Tanaman Hortikultura. Bhan Ajar Mata Kuliah. Institut Pertanian Bogor. Bogor.

Winarso, S. 2005. Kesuburan Tanah: Dasar Kesehatan Dan Kualitas Tanah. Penerbit Gava Media, Yogyakarta. 